\title{
2.9 Якість професійної діяльності науково-педагогічного працівника та її забезпечення
}

Сьогодні частіше говорять про якість вищої освіти, якість надання освітніх послуг, ніж про якість професійної діяльності науково-педагогічних працівників, хоча сумнівно, щоб без останньої можуть бути можливими дві попередні.

Насправді, якість професійної діяльності науково-педагогічних працівників важко визначити практично, оскільки вона виявляється в результатах навчання здобувачів вищої освіти, які також залежать від їхніх здібностей, попередньої підготовки, мотивації тощо. Разом з тим, на основі вивчення праць з проблем якості професійної діяльності науково-педагогічних працівників нами встановлено, що вона не тотожна ні поняттю “педагогічна майстерність", ні поняттю “педагогічна культура", ні поняттю “педагогічна компетентність”, ні поняттю “педагогічні здібності”, хоча й спирається на них.

Тому, щоб зрозуміти, в чому полягає якість професійної діяльності науково-педагогічних працівників, насамперед, розкриємо саму категорію “якість".

Вважають, що вперше до категорії “якість” звернувся Аристотель у своїх працях “Метафізика” і “Категоріі”, в яких розглядав якість предмета з точки зору його сутності, тобто предикаменту, що відповідає на запитання “який? ”. У відповіді передбачалася варіація з чотирьох можливих контекстів: 1) наявність чи відсутність уроджених (початкових, вихідних) здібностей та характеристик; 2) наявність і набутих, і стабільних властивостей; 3) наявність властивостей стану предмета чи явища, у процесі їхнього існування; 4) зовнішній вигляд предмета чи явища.

У гносеологічному вимірі Гегель під якістю розуміє початковий ступень пізнання речей, а в онтологічному - визначеність, яка $є$ тотожною $з$ поняттям “буття”. Разом з цим вчений пов'язує поняття якості з поняттями “кількість” і "міра", формулюючи закон про перехід кількості в якість. Розглядаючи діалектичну природу якості, Гегель указує на можливість вимірювання через неї істотної визначеності предмета. Власне, виходячи з цього, категорія “якість” у 
філософському вимірі і сьогодні розглядається як така, яка виражає істотну визначеність предмета, завдяки чому він існує у вигляді саме такого, а не іншого предмета [183, с.237].

Філософська думка така: «<..> Існують не якості, а речі, яким властиві певні якості, яких незліченна кількість» [184, с. 33]. Звідси слідує, що сутність поняття “якості” (у множині) одного об'єкта практично відповідає, тобто є ідентичною поняттю “властивості”».

I ще один важливий момент: у теорії управління якістю використовується поняття “процес", а не поняття “діяльність”. А якість процесів у певній системі залежить від їхніх властивостей. Відтак, вивчення якості професійної діяльності науково-педагогічних працівників пов’язане 3 виокремленням властивостей різних складових цієї діяльності, які відтворюють у собі їі істотні ознаки. Власне властивості є похідними від способів і змісту діяльності. I такою властивістю якості професійної діяльності науково-педагогічних працівників є іiі ефективність, яка, залежно від змісту і способів діяльності, обраної мети тощо, змінюється.

Оскільки професійна діяльність науково-педагогічних працівників - це процес, неперервний і складний, з багатьма невідомими, в якому переплетені та інтегровано проявляються його знання, вміння, компетентності, професійні здібності, особистісні якості, а також різні психологічні детермінанти тощо, то іiі кінцевий результат залежить від властивостей, що визначають ефективність цього процесу.

Власне професійна діяльність науково-педагогічних працівників є функціональною системою, то пï якість описується у прикметникових детермінантах. Так само описуються їі підсистеми. Але якість функціонування системи визначається якоюсь інтегративною властивістю. Оскільки якість процесів у системі індивідуальної професійної діяльності науково-педагогічних працівників зумовлюється результативністю цієї діяльності, то вона має бути ефективною. 
Отже, інтегрованою властивістю якості професійної діяльності науковопедагогічних працівників є її ефективність. Іншими словами, якість професійної діяльності науково-педагогічного працівника прямопропорційно залежить від іiі ефективності. В принципі, про це йдеться і у Великому тлумачному словнику сучасної української мови, в якому слово “якість” тлумачиться як: «<... Ступінь вартості, цінності, придатності чого-небудь для його використання за призначенням. 3. Та чи інша характерна ознака, властивість, риса кого-, чогонебудь. 4. Сукупність характеристик продукції або послуг щодо іiі здатності задовольнити встановлені та передбачені потреби. <...>» [185, с. 1423]. А слово “ефективний” означає такий функціональний стан, «1. Який приводить до потрібних результатів, наслідків, дає найбільший ефект (у 2 знач.). 2. Який викликає ефект (у 1 знач.)» [185, с. 358].

3 цих позицій, якість професійної діяльності науково-педагогічного працівника являс собою похідну від їі ефективності, котра с доцільно спрямованою за змістом, освітніми функціями та завданнями його керованою, мотивованою, емоційно позитивною, результативною психолого-педагогічною взаємодісю зі здобувачами вищої освіти, повною реалізацісю ним власних знань, умінь, загальних i фахових компетентностей, здібностей, особистісних властивостей та якостей.

Якісна професійна діяльність науково-педагогічного працівника на практичному рівні має виявляється як, по-перше, ефективно керований ними процес передання-оволодіння здобувачами вищої освіти професійними знаннями, вміннями і навичками, ефективний процес формуванням у них загальних і фахових компетентностей; по-друге, процес ефективної психологопедагогічна взаємодії зі здобувачами вищої освіти та іншими учасниками освітнього процесу; по-третє, процес ефективного здобуття новітніх фахових знань посередництвом наукової діяльності та їх доцільне (ефективне) впровадження в освітній процес; по-четверте, ефективний процес формування у здобувачів вищої освіти якостей, необхідних для професійної діяльності, суспільного й громадського життя. 
Постає питання про практичне забезпечення якості професійної діяльності науково-педагогічного працівника у закладі вищої освіти. Безумовно, є різні шляхи розв'язання цієї проблеми. Ми пропонуємо одну із моделей забезпечення якості професійної діяльності науково-педагогічного працівника. Для іiі розроблення, насамперед, уточнимо, що розуміється під терміном модель, який досить широко вживаний і в науковій літературі, і в різних галузях діяльності.

У більшості словників значення цього терміну розкривається так: «Модель (англ. model, нім. Modell, фр. modèle, від лат. modulus - “міра, аналог, зразок, взірець”) - відтворення чи відображення об’єкту, задуму (конструкцій), опису чи розрахунків, що відображає, імітує, відтворює принципи внутрішньої організації або функціонування, певні властивості, ознаки чи/та характеристики об’єкта дослідження чи відтворення (оригіналу).

У короткому словнику з логіки пояснюється, що “модель” (від лат. modulus - міра, зразок) у широкому сенсі розуміється як спеціально створений або спеціально підібраний об'єкт, котрий відтворює характеристики об'єкта, що вивчається [186, с. 112].

У найширшому значенні під поняттям “модель” розуміють певний образ об'єкта (зокрема, умовний чи уявний), котрий цікавить суб'єкта, або, навпаки прообраз деякого об’єкта чи певної системи об’єктів.

Часто під моделлю розуміють опис об’єкта (предмета, явища або процесу) на будь-якій формалізованій мові, складений 3 метою вивчення його властивостей. Це може бути i модель процесів, явищ (експеримент) для дослідження їх відтворюваності чи аналізу їхніх складових та ін.

Згідно з поглядами А. Катренко, модель є засобом осмислення дійсності, котра дозволяє впорядкувати та певним чином формалізувати первинні нечіткі або навіть, суперечливі уявлення про те чи інше явище, об'єкт, систему $[187$, с. 82$]$.

Для науковця А. Уємова модель являє собою систему, дослідження функціонування якої дозволяе одержати інформації про іншу систему [188, с. 48$]$. 
За В. Загвязінським, моделювання є однією 3 процедур дослідницької діяльності педагога, котра пов'язана 3 педагогічним проектуванням. Власне моделювання має за мету створення і моделі вихідного стану процесу чи об’єкта, який необхідно змінити, і моделі бажаного стану об'єкта на кінець запланованого періоду. Для цього потрібно виділити істотні ознаки, які присутні в оригіналі, та оптимізувати чи вдосконалити діяльність об'єкта, котрий вивчається [189, с. 45-46].

У педагогіці моделювання прирівнюють до теоретичного методу, за допомогою якого уточнюють, розширюють і систематизують наукові факти, розкривають і передбачають появу тих чи тих явищ, переходять від абстрактного до конкретного знання, встановлюють взаємозв'язки між різними поняттями й гіпотезами, виокремлюють серед них найбільш суттєві та другорядні за допомогою їх реальних чи ідеальних моделей [190, с. 12].

Дослідниця Л. Семушіна звертає увагу на те, що моделювання є одним із способів удосконалення професійної підготовки фахівців вищої школи. На іiі думку, матеріальним вираженням моделі професійної підготовки викладача або окремих його боків $є$ складові, зміст і послідовність надання студентам відповідних завдань, вправ, створення ситуацій, спрямування їхньої діяльності, що дозволяє охопити всі види його майбутньої професійної діяльності [191, с. 25].

Загалом моделі можуть бути:

- за змістом - повністю або переважно описовими;

- за складом, ієрархією компонентів - структурними;

- за характером зв'язків і засобів у дієздатності системи - функціональними або функціонально-динамічними;

- за можливістю встановлювати нові зв'язки та виявляти нові залежності евристичними;

- за принципами відображення в наявній моделі інших моделей інтегрованими.

Отже, більшість дослідників педагогіки розуміє моделювання як процес 
наукового пізнання У педагогіці на цей час розроблені різні моделі, в тому числі моделі фахівця, професійної діяльності, професійної підготовки тощо.

Приміром, О. Сердюкова розробила структурно-функціональну модель формування педагогічної компетентності майбутніх інженерів-педагогів у навчальному процесі закладу вищої освіти [192]. Дана модель складається 3 трьох взаємопов’язаних блоків: 1) орієнтувально-цільового, за допомогою якого передбачається «чітке визначення цілей i завдань діяльності професорськовикладацького складу щодо психолого-педагогічної підготовки майбутніх інженерів-педагогів, а також проведення попередньої діагностики сформованості в студентів педагогічної компетентності» [192, с. 117]; когнітивно-процесуального, що «передбачає конструювання цілісного педагогічного процесу, який забезпечує сформованість педагогічної компетентності майбутніх інженерів-педагогів...»; контрольно-оцінного, який «передбачає здійснення контролю, аналізу та корегування експериментальної роботи й отриманих результатів» [192, с. 131].

На підставі вищевикладених теоретичних аспектів моделювання вважаємо можливим розробити функціональну модель забезпечення якості професійної діяльності науково-педагогічного працівника. Вона має відповідати таким вимогам:

1) змістовності, тобто здатності моделі відображати істотні властивості та риси реального процесу професійної підготовки і професійної діяльності науково-педагогічного працівника в закладі вищої освіти;

2) відповідності, тобто відповідати тим завданням, які розв'язує науковопедагогічний працівник у ході своєї професійної діяльності під час досягнення мети освітнього процесу в сучасному інформаційному суспільстві;

3) системності, тобто відтворювати певну систему здобування науковопедагогічним працівником необхідних знань, навичок, вмінь, загальних i фахових компетентностей $з$ урахуванням постійної зміни знань, розвитку інформаційних технологій, а також формування особистісних властивостей i якостей та попередження їхнього руйнування; 
4) індуктивності, тобто урахування того, що якість професійної діяльності науково-педагогічного працівника забезпечується внаслідок трансформації сукупності окремих груп знань, навичок, вмінь, загальних i фахових компетентностей, особистісних властивостей і якостей до загальної здатності ефективного управління освітнім процесом здобувачів вищої освіти, ефективної взаємодії з ними, досягнення високих результатів у освітньому процесі тощо;

5) дедуктивності, тобто відображати можливість аналізу складових якості професійної діяльності науково-педагогічного працівника на основі результатів освітнього процесу і власної професійної діяльності;

6) синергійності, тобто надавання можливості, за умови функціонування всіх складових моделі, отримання бажаного кінцевого результату - високого рівня якості професійної діяльності науково-педагогічного працівника;

7) корегованості, тобто можливості зміни складових, що забезпечують якість професійної діяльності науково-педагогічного працівника, їх періодичне коригування;

8) прогнозованості, тобто забезпечувати можливість прогнозувати кінцевий результат - рівень якості професійної діяльності науково-педагогічного працівника;

9) вимірювальності, тобто можливість оцінювати якість професійної діяльності науково-педагогічного працівника;

10) адекватності, тобто адекватно відображати і наявні професійні знання, навички, вміння, загальні та фахові компетентності, і професійні здібності, і особистісні якості, і професійну спрямованість, і вибраний стиль управління освітнім процесом здобувачів вищої освіти, і мотивацію до ефективної професійної діяльності, і психолого-педагогічну професійну надійність, і в цілому якість професійної діяльності науково-педагогічного працівника, що є основою для корегування і прогнозування процесів, що перебігають у ній.

У процесуально-концептуальному контексті функціональна модель забезпечення якості професійної діяльності науково-педагогічного працівника це опис процесу забезпечення і підтримування в нього на високому рівні 
розвитку професійних знань, навичок, вмінь, загальних i фахових компетентностей, його особистісних якостей і властивостей, професійних здібностей, професійної спрямованості, мотивації до ефективної професійної діяльності та психолого-педагогічної професійної надійності.

За структурно-функціональним характером модель забезпечення якості професійної діяльності науково-педагогічного працівника являє собою систему психолого-педагогічних елементів (блоків) зі заданими характеристиками i властивостями, певним чином узгоджених за змістом, часом i метою, що відтворюють спрямовану професійну активність науково-педагогічного працівника та його особистісної організації в процесі взаємодії зі здобувачами вищої освіти з метою формування у них знань, навичок, вмінь, загальних i фахових компетентностей та особистісних якостей.

Функціональна модель забезпечення якості професійної діяльності науково-педагогічного працівника, як система, складається 3 певної сукупності відносно незалежних підсистем, функціонування яких здійснюється за своїми закономірностями. Приміром, окремими підсистемами $є$ формування i підтримування в науково-педагогічного працівника професійних знань, навичок, вмінь, загальних і фахових компетентностей; розвиток професійних здібностей та особистісних якостей; забезпечення позитивної професійної спрямованості; формування вмінь ефективного управління освітнім процесом здобувачів вищої освітив; формування мотивації до ефективної професійної діяльності; забезпечення психолого-педагогічної професійної надійності та ін. Кожна така підсистема у функціональному плані розгортається як своєрідний процес, що перебігає за своїми закономірностями, але разом з іншими підсистемами, не зважаючи на їх синергійний характер, у цілісному процесі функціонування моделі забезпечують певний рівень якості професійної діяльності науковопедагогічного працівника..

Дана модель відтворює реальний процес забезпечення якості професійної діяльності науково-педагогічного працівника щодо виконання всіх завдань освітнього процесу. Разом 3 цим вона дає можливість вивчення істотних 
властивостей складових, що визначають рівень розвитку професіоналізму і в цілому якості професійної діяльності науково-педагогічного працівника.

Результати наших досліджень свідчать, що функціональна модель забезпечення якості професійної діяльності науково-педагогічного працівника включає такі взаємопов’язані функціональні блоки: 1) знаннєвокомпетентнісно-особистісний; 2) професійно-мотиваційний; 3) професійноуправлінський; 4) професійно-орієнтаційний; 5) професійно-конструктивний.

Перший блок моделі - знаннєво-компетентнісно-особистісний забезпечує оволодіння науково-педагогічним працівником необхідною сукупністю загальних і фахових знань, постійне здобуття нових знань, формування вмінь, компетентностей, здібностей і особистісних якостей, a головне їх ефективну реалізацію ним в освітньому процесі.

Ми не будемо описувати, якими знаннями і вміннями повинен володіти НПП, оскільки вони добре розкриті в багаточисельних працях. Лише зробимо посилання на працю О. Гури [193], в якій, у принципі, як варіант, згруповані й систематизовані базові знання і вміння науково-педагогічного працівника, котрі необхідні йому для реалізації завдань освітнього процесу.

Але проблема забезпечення наявності у психолого-педагогічного працівника базових знань і вмінь, а також загальних і фахових компетентностей ускладнюється тим, що він має постійно використовувати в освітньому процесі нові знання, передові новітні (інноваційні) методи, технології та ін., якими, насамперед, має оволодівати самостійно. Виходячи з того, що в сучасному світі знання “старіють” дуже швидко, а новітні методи, технології та ін. з’являються часто, то науково-педагогічним працівникам не так легко оволодівати ними, оскільки їх потрібно, по-перше, вибрати із великого масиву інформації та осмислити, провести апробацію; по-друге, розробити на їх основі нові лекції, практичні й лабораторні заняття, практики, теми і методичні вказівки до курсових робіт (проектів) та ін.; по-третє, змінити відповідні програми, затвердити їх і под. 
Отже, у науково-педагогічного працівника має бути сформована готовність до безперервного процесу оволодіння новими знаннями самостійно i/чи колективно (коли заклад вищої освіти організовує здобуття нових знань у формі семінарів, конференцій, симпозіумів та ін.). Під такою готовністю розуміється наявність у нього і вмінь до здобуття нових знань, і мотивації, і засобів.

На основі професійних знань і вмінь у науково-педагогічного працівника формуються загальні та фахові компетентності як здатності до розв'язання різних завдань освітнього процесу.

Таке визначення компетентності базується на розгорнутій у 1997 році в країнах Європи програмі “Визначення та відбір компетентностей: теоретичні й концептуальні засади", основне завдання якої полягало в систематизації та узагальненні результатів десятирічних досліджень 3 проблем компетентностей, які необхідні фахівцю сучасного суспільства. На основі цієї програми експерти визначають компетентність як «здатність успішно задовольняти індивідуальні й соціальні потреби, діяти та виконувати поставлені завдання» [194]. 3 цих позицій компетентність складається 3 низки компетенцій, кожна 3 яких побудована на комбінації (поєднанні, переплетенні) взаємовідповідних пізнавальних зв'язків і практичних навичок, цінностей і поведінкових компонентів, знань і вмінь, емоцій і волі, іншими словами, всього того, що уможливлює активну діяльність.

Загалом, експертами Європейського освітнього фонду $(1997$ р.) компетентність описується як, по-перше, здатність виконувати будь-що гарно та ефективно; по-друге, критерій відповідності певним вимогам при прийомі на роботу; по-третє, спроможність виконувати особливі трудові функції [195].

У матеріалах ЮНЕСКО окреслена сукупність компетентностей, котрі визнаються як результат освіти. У цьому контексті в доповіді міжнародної комісії з освіти XXI ст. “Освіта: приховані скарби” Ж. Делор визначив чотири базові чинники сьогоднішньої освіти: навчити пізнавати, навчити працювати, навчити жити спільно, навчити жити самостійно [196].

Ми підтримуємо позицію О. Сердюкової, згідно 3 якою, «сутність компетентності особистості як цілісного наукового феномену, що виявляється як 
інтегрована характеристика особистості й визначає іiі готовність використовувати засвоєні знання, вміння, навички й набутий досвід та особистісні якості для успішного розв'язання різноманітних за змістом і складністю завдань, що виникають у процесі життєдіяльності та професійній cфepi» [192].

Важливою складовою першого блоку також $\epsilon$ наявність у науковопедагогічних працівників особистісних якостей, необхідних для реалізації завдань сучасного освітнього процесу.

Зауважимо, що особистісні якості викладача часто розглядаються через призму його компетентності. Так, в американській моделі “компетентнісного працівника”, яка розроблена Д. Меридлом, Д. Джюлом та І. Стевіком, визначені такі професійно-важливі якості фахівця, як дисциплінованість, самостійність, комунікабельність, прагнення до саморозвитку. Особливо звертається увага на наявність такої якості як спроможність особистості до саморозвитку, котра, на їхню думку, має забезпечити не лише усвідомлений процес формування фахової майстерності, самоосвіти й самовдосконалення, а й мотивований, цілеспрямований вільний вибір і прагнення фахівця досягнути бажаного рівня професійної компетентності.

На думку Б. Гершунського, «професійна компетентність, по-перше, - це функціональна грамотність, яка використовується й актуалізується на власне професійному рівні; по-друге, це такі іiі компоненти, які можуть бути віднесеними не стільки до предметного змісту, скільки до якостей особистості, що формуються, - відповідальності, творчості, допитливості, наполегливості, прагнення до набуття нових знань і, звичайно ж, до високої моральності, без якої не мислиться справжній професіонал своєї справи» [198, с. 123].

Всі особистісні якості науково-педагогічних працівників мають певну професійну значущість. Так, для успішної взаємодії зі здобувачами вищої освіти науково-педагогічний працівник має бути дисциплінованим, цілеспрямованим, ініціативним, обов’язковим, вимогливим до себе та інших. Разом з цим важливими для нього є такі якості як витримка, здатність до гальмування у 
поєднанні зі швидкою реакцією й винахідливістю, емоційна толерантність, доброзичливість, емпатійність, співчутливість тощо. Необхідними якостями науково-педагогічних працівників $є$ педагогічна спостережливість, яка допомагає йому отримувати інформацію про індивідуальні особливості студентів, їхнє ставлення до навчання, інших студентів і науково-педагогічних працівників, розуміння навчального матеріалу, про стосунки між ними, настрої, бажання, характер їхнього реагування на зауваження, оцінку (бал) тощо.

Загалом науково-педагогічний працівник має:

- досконало володіти мовою, що забезпечує логічність і чіткість подання навчального матеріалу, переконливість, впливовість, здатність викликати у студентів позитивні почуття;

- бути людяним, доброзичливим, толерантним, емоційно стійким, емоційно привабливим, виваженим, доступним для здобувачів вищої освіти, наполегливим, дисциплінованим, відповідальним, порядним, у міру принциповим, справедливим,

- педагогічно мислити, тобто застосовувати теоретичні положення філософії, психології, педагогіки, методики у конкретних педагогічних ситуаціях освітнього процесу;

- бути оптимістом, оскільки його оптимізм позитивно впливає на ефективність навчальної діяльності студентів, їх виховання, викликаючи у них позитивні емоції, захопленість справою тощо;

- виявляти педагогічний такт, який полягає в його здатності тактично, урівноважено, толерантно, з повагою і розумінням ставитися до студентів та їхніх проблем, ні в якому разі своєю поведінкою не показувати свою неповагу, байдужість, неприязнь, зверхність та ін.

До цього блоку також належать організаційні і комунікативні здібності.

Дослідник Л. Подоляк і В. Юрченко доводять, що «одним із складників професіоналізму діяльності викладача вищої школи $є$ його організаторські здібності <..> » [199, с.129]. Розгортаючи думку, вони пояснюють, що «управління в системі “особистість-особистість” полягає в реалізації керівником 
конструктивної, регулятивної, комунікативної та оцінно-корегувальної функцій, які забезпечують ефективний вплив на людей, щоб гарантовано виконувати завдання сумісної діяльності. Сутність такої діяльності полягає в організації мотивованих відносин у колективі задля успішного вирішення навчальновиховних завдань» [199, с.134].

Власне організаційні та комунікативні здібності науково-педагогічних працівників є провідними, оскільки вони найбільшою мірою необхідні в освітньому процесі, а у практичному контексті в них інтегровано відображаються майже всі інші здібності.

Як відомо, здібності $є$ індивідуально-психологічними особливостями особистості, які сприяють успішному здійсненню будь-якої діяльності. Вони, безумовно, залежать від навичок і вмінь, але не зводяться до них. Згідно 3 Б. Тепловим, здібності утворюються в діяльності та проявляються в таких іiі динамічних характеристиках, як швидкість, глибина, міцність засвоєння [200]. Науково-педагогічний працівник, як організатор, повинен володіти сукупністю організаторських здібностей, необхідних для реалізації завдань освітнього процесу.

Науково-педагогічний працівник має вміти організовувати роботу здобувачів вищої освіти щодо вивчення конкретного предмету. Надзвичайно важливими для організаторської діяльності науково-педагогічних працівників $\epsilon$ такі його риси характеру, як дисциплінованість, самоорганізованість, енергійність, самоволодіння, рішучість, принциповість, вимогливість, логічність, тактовність та ін. Разом з цими також важливими $є$ такі його риси як простота, доступність, природність у поводжені, привітність та ін.

Ефективність організаторської діяльності науково-педагогічних працівників тісно пов'язана з рівнем розвитку його організаторських здібностей. Дослідник О. Ковальов стверджує, що організаторські здібності тісно пов'язані 3 характерологічними рисами особистості, а комунікативні риси характеру чуйність, уважність до людей і справедливість, своєю чергою, є допоміжними 
властивостями організаторських здібностей, оскільки за їх посередництва особистість розуміє інших людей та особливості спілкування з ними [201].

3 цих позицій організаторські здібності науково-педагогічного працівника виявляються як його індивідуально-психологічні властивості, за допомогою яких він має змогу встановити контакт зі здобувачами вищої освіти, визначити підходи та умови, шляхи i способи досягнення ними найефективніших результатів навчання, організувати взаємодію, визначити місце i час консультування, доцільного використання інформаційних технологій та ін.

Отже, організаторські здібності науково-педагогічного працівника - це його здатність організувати свою власну діяльність у відповідності до потреб перебігу освітнього процесу, а також навчальну діяльність здобувачів вищої освіти, розв'язувати проблеми, що виникають, та ін.

За результатами дослідження Л. Мотозюк, структурними елементами організаторських здібностей є наявність: 1) високого рівня вольової організації особистості; 2) інтелекту, що відповідає високому та середньому рівню; 3) високого рівня розвитку специфічних якостей особистості (психологічної впливовості, комунікативної компетентності, психологічної проникливості, схильності до лідерства) [202].

Завдяки своїм організаторським здібностям науково-педагогічний працівник реалізує функцію планування, контролю, корегування та регулювання i стосунків зі здобувачами вищої освіти, студентськими групами, i їхньої діяльності, і своєї власної діяльності.

Надзвичайно важливими для науково-педагогічного працівника $є$ його комунікативні здібності.

Різні боки комунікативних здібностей розкриті у багатьох працях, у тому числі К. Абульханової-Славскої, В. Галузяк, Ю. Жукова, О. Кідрона, І. Коваля, Ж. Максименко, Є. Михайлової, О. Опалюк, Г. Почепцова, М. Савчина, А. Смірнова, Т. Чмут, Х. Яусс, Р. Чуваттанакуль, Г. Гладштейн, Дж. Сабіні, С. Уорнер, М. Уілтс. 
Так, дослідник О. Кідрон під комунікативними здібностями розуміє загальну здатність, пов'язану з різноманітними підструктурами особистості, що виявляється в навичках суб'єкта спілкування вступати в соціальні контакти, регулювати ситуації взаємодії, а також досягати в міжособистісних стосунках комунікативну мету. Автор вважає, що здатність особистості до комунікації в найбільш загальному вигляді виражається в його вмінні встановлювати соціальні контакт з іншими людьми, входити в різні ролі, досягати взаєморозуміння в різних умовах інтеракції і на різних рівнях обміну інформацією. На особистому рівні у структурі комунікативних здібностей О. Кідрон виділяє чотири рівні: 1) базовий рівень, який відображає комунікативний потенціал людини і суспільні та особистісні передумови спілкування: комунікативні засоби, схема орієнтації інтеракції, зовнішність, темперамент, статус індивіда; 2) нижчий рівень, для якого характерно володіння лише певними навичками спілкування; 3) середній рівень, на якому сформовані вміння спілкуватися; 4) вищий рівень, коли використовуються форми інтеракційного пристосування і реалізується спрямованість поведінки.

Комунікативні здібності науково-педагогічного працівника виявляються в його комунікативній успішності, котра відображає результативність комунікації зі здобувачами вищої освіти. Зазначимо, що комунікативна успішність досить часто ставиться поряд із поняттям “комунікативна компетентність” і “соціальна компетентність”, “соціальний інтелект”, соціально-перцептивні вміння і навички, соціальна обдарованість, лідерство та ін. [204].

Комунікативні здібності виявляються за умови доцільного та успішного використання вербальних і невербальних засобів спілкування, оскільки словами передається чиста інформація, а по невербальних каналах трансформується ставлення до партнера по спілкуванню, емоційний стан співрозмовника та ін. За результатами дослідження Ф. Зимбардо i M. Лейппе через невербальну поведінку розкривається внутрішній світ особистості, здійснюється формування психічного змісту спілкування та спільної діяльності. Люди досить швидко 
можуть найти способи пристосування до обставин, які змінюються, але мова тіла виявляється менш пластичною [205, с. 88].

Отже, комунікативні здібності науково-педагогічного працівника являють собою його здатність до ефективного спілкування та взаємодії зі здобувачами вищої освіти, спрямовану на організацію та оволодіння ними знаннями, навичками, вміннями і загальними та фаховими компетентностями.

Науково-педагогічний працівник у процесі своєї професійної діяльності застосовує ділову (офіційну) і не ділову (не офіційну) комунікацію. У діловій комунікації, на що вказує А. Панфілова, предметом спілкування є діяльність і справа, а партнер по спілкуванню розглядається як значуща особистість [206].

Головними завданнями ділової комунікації науково-педагогічного працівника зі здобувачами вищої освіти $є$ створення ділової академічної атмосфери, в якій можливі продуктивна співпраця, взаєморозуміння, особиста відповідальність учасників освітнього процесу, визначення спільної мети i шляхів іiі досягнення, звітування за виконану навчальну роботу, адекватне принципове оцінювання результатів навчання, критика і самокритика та ін.

Психолого-педагогічними умовами ефективної ділової комунікації науково-педагогічного працівника зі здобувачами вищої освіти $є$ :

- вміння чітко окреслити предмет розмови, доступно і зрозуміло довести його до співрозмовників;

- здатність доречно говорити і вчасно замовчати;

- $\quad$ вміння слухати і розуміти проблеми здобувачів вищої освіти;

- здатність бути емоційно толерантним до всіх учасників спілкування;

- здатність “розшифровувати” невербальні засоби комунікації та адекватно реагувати на них;

здатність доброзичливо і неупереджено ставитися до всіх учасників спілкування, незалежно від симпатій та антипатій до них;

- знання і розуміння психологічних особливостей молодих людей студентського віку; 
- вміння дотримуватися формально-рольових принципів взаємодії 3 урахуванням субординації та ділового етикету;

- вміння робити зауваження і критикувати так, щоб не зашкодити честі й гідності особистості здобувача вищої освіти;

- вміння вести розмову зрозумілою і доступною мовою;

- здатність не перебивати співрозмовника доти, доки той повністю не висловився;

- вміння створити сприятливу психологічну атмосферу в процесі спілкування;

- здатність визначати мотиви і потреби здобувачів вищої освіти;

- вміння використовувати практичні прийоми переконання в ході комунікації;

- здатність здійснювати комунікацію зі здобувачами вищої освіти на основі сумісності й психологічного партнерства, за яких головним способом комунікації є розмова "рівного з рівними”.

Ділова комунікація науково-педагогічного працівника $є$ складним процесом, що уможливлюється внаслідок наявності в нього комунікативних здібностей, в яких інтегровано відображені вміння критично осмислювати власний комунікативний досвід, комунікативна культура, світогляд, знання психологї̈ спілкування та психологічних вікових особливостей здобувачів вищої освіти, їхнього ставлення до навчання, знання змісту освітнього процесу, характер його організації та перебігу тощо.

Сучасний заклад вищої освіти - це комунікаційна система, яка постійно розвивається, реагуючи на актуальні зміни, що відбуваються в суспільстві та у світовому освітньому просторі, через яку здійснюється вплив на здобувачів вищої освіти 3 метою і оволодіння ними загальними та фахових знаннями, вміннями, компетентностями, і формування у них адекватного світогляду, особистісних та громадянських якостей, і підготовки до суспільного життя.

Отже, знаннєво-компетентнісно-особистісний блок можна виразити через такі його складові як: 1) сукупність знань, умінь, компетентностей, необхідних 
якостей та їх ефективна реалізація в освітньому процесі; 2) організаційні здібності; 3) комунікативні здібності.

Другим блоком моделі є професійно-мотиваційний, котрий забезпечує формування в науково-педагогічного працівника мотивації до професійної діяльності.

Наявність у науково-педагогічного працівника професійних знань, умінь, компетентностей та особистісних якостей ще не гарантує їх ефективну реалізацію ним в освітньому процесі. Потрібно, щоб науково-педагогічний працівник бажав, прагнув реалізувати їх в освітньому процесі, тобто, щоб він був мотивований до ефективної професійної діяльності. Адже буває, що у процесі професійної діяльності науково-педагогічний працівник утрачає мотивацію до ії якісного виконання. Це найчастіше виявляється і як відсутність мотивації до досягнення успіхів у професійній діяльності, і як поява мотивації до уникнення в ній невдачі, тобто уникнення ризику отримати негативний результат унаслідок впровадження в освітній процес чогось нового, передового, такого, що раніше не використовувалося.

Мотиваційна сфера науково-педагогічних працівників суттєво детермінує якість професійної діяльності науково-педагогічного працівника, оскільки спонукає до свідомого вибору ним того або іншого типу поведінки, що визначається комплексною дією зовнішніх (стимулів) і внутрішніх (мотивів) чинників.

Цілком вірно зазначає М. Ярошевський, який вказує на те, що мотивація є енергетичним компонентом будь-якої діяльності: «Які б дії не розпочинала людина, яким би високим не був ступінь їхньої усвідомленості й логічної продуманості, жоден зовнішній або внутрішній акт поведінки не може бути виконаний без його мотиваційної, а значить - енергетичного забезпечення».

Значна кількість дослідників, у тому числі й О. Леонтьєв, С. Рубінштейн і Д. Узнадзе вважають, що мотив є центральним, системоутворювальним фактором діяльності.

На ефективність професійної діяльності науково-педагогічних працівників 
впливають різні мотиви. На думку Л. Орбан-Лембрик, мотиваційну сферу відповідальної поведінки керівника (а науково-педагогічний працівник керує освітнім прочесом здобувачів вищої освіти - Ю.М.) 3 погляду ієрархії потреб утворюють такі групи мотивів: 1) прагматичні мотиви (намагання розглядати свою поведінку, управлінські вчинки крізь призму користі, насамперед для себе; виявляється у задоволенні власних потреб); 2) соціальні мотиви (оскільки робота керівника є однією з найвідповідальніших у суспільстві, то багато управлінців прагнуть діяти відповідально, дбаючи про наслідки своїх вчинків для суспільства, намагаються поведінкою, справами принести користь державі); 3) мотиви самопізнання, саморозвитку, самоаналізу, саморегуляції, самореалізації (зумовлені потребою реалізувати у конкретній спільній справі свої управлінські можливості й здібності, пов'язані 3 необхідністю пізнати себе, оцінити свої сили та вміння); 4) мотиви морального самоствердження (зумовлені прагненням утвердити себе в статусі керівника - моральної особистості); 5) правові мотиви (погляд на свою управлінську діяльність і відповідальність з позицій закону); 6) мотиви спілкування і взаємодії (вони є однією з передумов спільної управлінської діяльності); 7) мотиви егоїстичного самоствердження (викликані намаганням привернути до себе увагу, продемонструвати свою перевагу над іншими); 8) мотиви, пов'язані із специфічними особливостями особистості керівника (залежність керівника від вищого управлінського апарату, який нав'язує свій варіант розв'язання управлінської проблеми; намагання уникнути критики, покарання, осуду тощо) [208].

В структурі мотивації науково-педагогічного працівника домінують соціальні та прагматичні мотиви. Отже, це свідчить, що науково-педагогічні працівники діють відповідально тоді, коли одночасно задовольняють власні потреби та потреби суспільства. Вчений $Є$. Ільїн називає це явище мотиваційноцільовим резонансом. «Мотиваційно-цільовий резонанс - співпадіння особистих цілей та мотивів з соціально-цінними мотивами» [209, с. 344].

Спонукальні чинники особливо сильні тоді, коли здобувачі вищої освіти і 
науково-педагогічні працівники відчувають відповідальність за досягнення поставленої мети та їі результати. Що більшу відповідальність відчувають учасники педагогічної взаємодії за наслідки своєї діяльності, тим сильніше мотивовані їхні різнобічні дії.

Важливою для ефективності професійної діяльності науково-педагогічних працівників є мотивація до досягнення успіху, яка, на думку Г. Мюррея, виражається у потребі долати перешкоди, досягати високих показників у діяльності, постійно самовдосконалюватись, конкурувати 3 іншими та випереджувати їх, реалізовувати свої здібності і таким чином підвищувати самоповагу.

Мотивація до досягнення успіху полягає у прагненні рухатися вперед та покращувати свої результати, шукати нові шляхи досягнення мети, не задовольнятися досягнутим та ін. Так, В. Ковальов указує на те, що існує тісний взаємозв’язок між рівнем мотивації досягнення та успіхом у життєдіяльності [211]. Виявлено, що науково-педагогічні працівники, які мають високий рівень цієї мотивації, шукають шляхи і способи досягнення мети, вони впевнені в успішному результаті, використовують нові ідеї, діють рішуче у невизначених ситуаціях, не розгублюються, сміливо долають перешкоди.

Мотивація до досягнення успіху, яка є провідною у процесі професійної діяльності науково-педагогічних працівників, забезпечує розвиток їх здатності оперативно і творчо розв'язувати нові педагогічні завдання і проблеми в умовах освітнього процесу. Відсутність вираженого прагнення до успіху та вдосконалення, намагання уникнути невдач може призвести до виникнення у науково-педагогічного працівника професійної кризи, але точно негативно впливає на якість його професійної діяльності.

Отже, професійно-мотиваційний блок якості професійної діяльності науково-педагогічного працівника виражається такими складовими, як: 1) мотивація до успіху; 2) відсутність мотивації до уникнення невдачі, що має обернено пропорційну залежність від мотивації до уникнення невдач. 
Третій блок моделі - професійно-управлінський, котрий забезпечує ефективне управління НПП освітнім процесом здобувачів вищої освіти.

Психолого-педагогічні та психологічні аспекти управління науковопедагогічними працівниками освітньою діяльністю здобувачів вищої освіти розглядали дослідники педагогічної психології та педагогіки вищої школи А. Алексюк, Ю. Бабанский, О. Власова, І. Зазюн, Д. Столяренко, Н. Творогова, Є. Шиянов, В. Якунін та ін.

Сутність управління науково-педагогічного працівника освітнім процесом, як виду діяльності, можна розуміти, виходячи 3 досліджень Б. Ломова, який наголошує, що «психологія саме і розглядає в діяльності той аспект, який пов'язаний із вивченням різних форм, видів і рівнів суб'єктивного відображення об’єктивної дійсності діючою людиною. У дослідженні діяльності її передусім цікавлять мотиви, цілеутворення, воля, емоції та ін., які становлять собою специфічні форми суб'єктивного відображення суспільних відносин <..>» [212, с. 205]. Наголошуючи на універсальності будови будь-якого виду діяльності, Б. Ломов виділяє в ній такі головні функціональні блоки як: мотив, мета, планування, перероблення інформації, оперативний образ або концептуальну модель, прийняття рішення, дії, перевірка результатів дій та їх корекцію [212, с. 216].

Загалом професійна діяльність науково-педагогічного працівника закладу вищої освіти $\epsilon$ поліфункціональною, оскільки він в освітньому процесі водночас реалізує багато функцій. Здавалося б, що ці функції незалежні одна від одної, проте прискіпливий аналіз освітнього процесу в сучасному інформаційному світі свідчить, що провідною, точніше його головною функцією є управлінська. Власне всі інші функції реалізуються в освітньому процесі через її призму.

Так, згідно з поглядами А. Алексюка [213], у закладі вищої освіти предметом педагогічної діяльності є управління освітнім процесом здобувачів вищої освіти, у тому числі і їхнім професійним розвитком. Проте ще раніше російський дослідник В. Якунін весь процес освіти загалом розглядає в ракурсі системного підходу і теорії управління [214, с. 19-52]. 
Стосовно управлінської функції, то в деяких працях цілком вірно наголошується, що науково-педагогічний працівник повинен “не вчити, а спрямовувати учіння” [215, с. 232].

Ми повністю підтримуємо позицію дослідників, які стверджують, що управлінська функція $є$ головною у професійній діяльності науковопедагогічного працівника, оскільки в умовах наявності великої кількості знань (інформації), котрі постійно розширюються, змінюються й оновлюються, він повинен організувати освітній процес так, щоб здобувач вищої освіти, по-перше, навчився сам вибирати найефективніші 3 них для розв’язання конкретної проблеми, яка перед ним виникла; по-друге, був готовим вчитися все життя i творчо розв'язувати будь-яке завдання. Адже, навіть, одне й те саме завдання можна розв’язати багатьма способами, в тому числі й неординарними.

Українські дослідники Л. Подоляк і В. Юрченко прямо заявляють, що «студент є об єктом управління викладача, оскільки діяльність останнього спрямована на зміни особистості майбутнього фахівця». «Функція управління це та роль, яку виконує керівник на певному етапі управління відповідно до поставленої мети». До головних функції управління освітнім процесом автори відносять: 1) проективну функцію, тобто визначення мети і завдань навчання; 2) конструктивну функцію, тобто розробка інструментарію (методів, прийомів тощо) забезпечення освітнього процесу; 3) організаторську і регулятивну функції, тобто практичну організацію освітнього процесу; 4) комунікативну функцію; 5) оцінно-корегувальну функцію. Автори пояснюють: «Залежно від стратегії навчання студентів реалізація кожної 3 функцій педагогічного управління має свою специфіку, на основі якої можна визначити різні моделі управління: модель 1 - авторитарна, пряма й жорстка (у минулому); модель 2 демократична, опосередкована й гуманістична» [199, с. 130-134].

Автори навчального підручника “Вікова та педагогічна психологія”, показуючи “лінії руху досліджень з проблем психології навчання” дійшли висновку, що вони «групуються навколо двох характеристик: по-перше, навчання розуміють як управління процесом учіння, по-друге, виявлення 
можливостей пізнавальної активності учнів, формування умінь “добувати", знання самостійно» [216, с. 316-317].

Дослідники А. Нісімчук, О. Падалка і О. Шпак прямо вказують на те, що педагогічна діяльність «спрямована на реалізацію управління і формування навчальної діяльності того, хто навчається <...>» [217, с. 53].

За допомогою ефективного управління науково-педагогічний працівник спрямовує та активізує пізнавальну діяльність здобувачів вищої освіти, зменшує вплив дестабілізуючих чинників, оптимізує освітнє середовище з метою їх підготовки до фахової діяльності та суспільного життя. Проте здійснення такого управління можливе за умов використання адекватного психологічного підгрунтя.

Вчений М. Найдьонов важливу роль відводить “рефлексивному управлінню", котрому «надається значення спеціалізації управління, яке містить у собі підсистему управління рефлексивним процесом і відбувається як щодо сталих суб’єктів, так і щодо суб'єктів, які перебувають на стадії становлення <...> $[218$, с. 295$]$.

Психолого-педагогічні впливи, взаємодію, контроль і оцінювання рефлексують як науково-педагогічні працівники, так і здобувачі вищої освіти. Таким чином відбувається управління рефлексивним процесом у континуумі індивідуально-групового суб'єкта. Фактично мова йде про особистісну і групову рефлексію. Взаємодія, взаємоузгодження і взаєморозуміння в ході навчальної діяльності здійснюються посередництвом інтелектуальної та особистісної рефлексії як студентів, так і науково-педагогічних працівників.

Можливість особистісної, групової, міжсуб’єктної, змістовної та інтелектуальної рефлексії в ході розв'язання змістовно-смислових педагогічних завдань і порівняння результатів 3 наявною моделлю дає можливість науковопедагогічному працівнику переосмислити форми, методи i засоби управлінського впливу. 3 іншого боку це забезпечує змістовно-смисловий аналіз освітнього процесу.

Звернемо увагу на те, що на центральності управлінської функції 
грунтується і головна ідея Болонського процесу, яка полягає в тому, що здобувач вищої освіти повинен сам “здобувати” знання, а завдання науково-педагогічного працівника полягає у здійсненні управління цими процесами, його поведінкою і мотивацією.

Стиль управління науково-педагогічного працівника освітньою діяльністю здобувачів вищої освіти може бути авторитарним, демократичним або ліберальнопотуральним, які досить повно представлені та охарактеризовані у працях Р. Бойца, В. Болотова та Є. Ісаєва, Л. Макарової, В. Мерліна та ін.

Проте той чи інший стиль майже не зустрічається в чистому вигляді - як правило, реально спостерігається поєднання різних стилів при домінуванні одного. Приміром, сучасні дослідники доводять, що існують такі ситуації, коли найбільш продуктивним та адекватним може бути лише авторитарний стиль [219].

Нами виявлено, що якість управління освітнім процесом студентів визначається доцільністю поєднання науково-педагогічним працівником авторитарного та демократичного стилів управління.

Головними позитивними характеристиками демократичного науковопедагогічного працівника є справедливість, повага до здобувачів вищої освіти, турбота про них, урахування їхніх думок, висування своїх вимого у формі пропозицій, порад, прохань тощо.

Однак, коли здобувач вищої освіти не прикладає зусиль до виконання окремих педагогічних завдань, наприклад, формально ставиться до написання курсової роботи, замість самостійної праці “завантажує” ії з мережі Інтернет, то науково-педагогічному працівникові у цьому випадку доцільно застосувати авторитарний стиль управління, не зарахувавши іiі і примусивши здобувача вищої освіти заново самостійно написати курсову роботу.

Ліберальний (пасивний) стиль управління характеризується тим, що науково-педагогічний працівник надає здобувачам вищої освіти майже повну волю у виборі форм і методів учіння, виконання освітніх завдань, уникає спілкування і взаємодії з ними, або навпаки, говорить багато, але в загальному, щоб сподобатися, не ініціює нові справи, виявляє невимогливість і 
безконтрольність до виконання ними навчальних завдань, не виконує обіцянки та ін. [220].

Для якісної професійної діяльності науково-педагогічний працівник має не лише вміло поєднувати авторитарний i демократичний стилі управління, уникаючи пасивного (ліберального), але і здійснювати науково обгрунтоване управління освітнім процесом, розвитком (саморозвитком) i фаховою підготовкою здобувачів вищої освіти.

Отже, професійно-управлінський блок можна виразити через такі його складові, як: 1) авторитарно-одноосібний стиль управління освітнім процесом здобувачів вищої освіти; 2) одноосібно-демократичний стиль управління освітнім процесом здобувачів вищої освіти; 3) відсутність пасивного стилю управління освітнім процесом здобувачів вищої освіти, що має обернено пропорційну залежність від пасивного стилю управління.

Четвертий блок моделі - професійно-орієнтаційний, через який забезпечується позитивна професійна спрямованість науково-педагогічного працівника.

Ми вважаємо, що професійна спрямованість науково-педагогічного працівника є похідною від його поведінки і взаємин зі здобувачами вищої освіти, котра в цілому являє собою активну ланку його управлінської функціональнопроцесуальної системи.

Професійна спрямованість особистості залежить від спрямованості іiі психіки. На це звертає увагу дослідник В. Москалець, який підкреслює, що «суспільна природа особистості формовиявляється у іï знаннях, уміннях, навичках та утвореннях, що належить сфері спрямованості ii психіки» [221, с. 22].

На нашу думку, це лише доповнює зміст професійної спрямованості науково-педагогічного працівника, оскільки і вона реалізується мотивованою цілеспрямованою поведінкою, що становить собою діяльність щодо досягнення корисного, в даних умовах, результату. 
До основних критеріїв цілеспрямованої поведінки закордонні дослідники А. Ньюелл і Г. Саймон відносять: 1) визначені підцілі; 2) засоби досягнення підцілей і мети; 3) уникнення повторень; 4) насичення. За умови досягнення системою бажаного стану чи близького до нього, вона завершує своє функціонування на тому підгрунті, що мети досягнуто.

Рівень якості змісту професійної спрямованості науково-педагогічного працівника, на нашу думку, адекватно можна виразити через три вектори його активності: перший вектор - “спрямованість на себе”, другий - “спрямованість на формальну взаємодію”, третій - “спрямованість на справу”.

За вектором “спрямованість на себе”, науково-педагогічний працівник закладу вищої освіти більшою мірою вирішує свої проблеми, залишаючи поза увагою проблеми освітнього процесу.

Діяльність викладача за вектором “спрямованість на формальну взаємодію” характеризується формальним його ознаками ставленням до виконання своїх обов'язків, імітацією науково-педагогічної активності. Головна мета такого викладача, з одного боку, - сподобатися здобувачам вищої освіти, а з іншого уникнути скарг, нарікань, критики за безплідну діяльність. Тому він всяко старається не конфліктувати зі здобувачами вищої освіти, не критикувати їх, навіть, за серйозні недоліки. Але разом з цим він не вникає в їхні справи і проблеми, не контролює виконання ними освітніх завдань тощо.

Позитивним вектором професійної спрямованості, який суттєво впливає на якість освітнього процесу, є “спрямованість на справу”, що характеризується його зосередженістю на освітньому процесі, на вивченні та розв'язанні проблем здобувачів вищої освіти, наданням їм практичної допомоги з різних питань. Такий викладач виявляе принциповість і вимогливістю до здобувачів вищої освіти, завжди намагається покращити умови освітнього процесу, впровадити нові форми, методи, педагогічні та інформаційні технології тощо.

Отже, професійно-орієнтаційний блок охоплює такі головні складові: 1) відсутність спрямованості на себе, що має обернено пропорційну залежність від спрямованості на себе; 2) відсутність спрямованості на взаємодію, що має 
обернено пропорційну залежність від спрямованості на взаємодію; 3) спрямованість на справу.

П'ятий блок моделі - професійно-конструктивний, через який забезпечується психолого-педагогічна професійна надійність науковопедагогічного працівника.

Роками на професійну діяльність науково-педагогічного працівника впливають різні як суб’єктивні, так і об’єктивні чинники, які, безумовно, можуть погіршувати їі якість. У випадку, коли якість професійної діяльності науковопедагогічного працівника залишається високою тривалий час, то доречно говорити про його психолого-педагогічну професійну надійність, під якою найчастіше розуміють сталість його фахових компетентностей, особистісних якостей та здібностей, здатності завжди будувати найдоцільніші взаємини зі здобувачами вищої освіти, реалізовувати найефективніший стиль управління освітнім процесом, постійно здобувати найсучасніші передові знання і втілювати їх в освітній процес тощо.

Психолого-педагогічна професійна надійність науково-педагогічного працівника формується за наявності в нього: 1) професійно-когнітивної надійності; 2) професійно-вольової надійності; 3) професійно-емоційної надійності; 4) персоналізації; 5) значущості особистісних досягнень.

Так, професійно-когнітивна надійність науково-педагогічного працівника являє собою стійку, стабільну інтелектуальну його здатність до якісного розв’язання освітніх завдань, креативність та ефективність мислення, інтелектуальну активність і творчість; професійно-вольова надійність високий рівень вольової стійкості, дисциплінованості, самоорганізації, цілеспрямованості й наполегливості в досягненні високих результатів у науковопедагогічній діяльності; професійно-емоційна надійність - здатність генерувати позитивні емоції, бути емоційно чуттєвим до здобувачів вищої освіти, емоційно стійким та толерантним у процесі педагогічної взаємодії з ними; персоналізація (лат. Persona - особистість) - потреба в прояві своєї особистості, усвідомлення власної особистості як суспільно значущої, результатом чого 
виступає його активна освітня діяльність, спрямована на трансляцію іншим своєї індивідуальності; значущість особистісних досягнень - ціннісне ставлення до результатів своєї професійної діяльності, визнання їхньої важливості, значущості.

Психолого-педагогічна професійна надійність науково-педагогічного працівника пропорційно обернена до його психолого-педагогічної професійної деформації, яка розвивається на підгрунті професійного вигоряння, під яким ми розуміємо втрату ним фахової здатності до якісного розв'язання освітніх завдань унаслідок руйнування або старіння попередньої системи знань, умінь i компетентностей, викривлення фахових і особистісних якостей та властивостей, утрати професійної мотивації до досягнення успіху на основі когнітивного, вольового та емоційного вигоряння, деперсоналізації та редукції особистісних досягнень.

Отже, в основі психолого-педагогічної професійної деформації науковопедагогічного працівника лежить його професійне вигоряння, яке охоплює: 1) професійно-когнітивне вигоряння; 2) професійно-вольове вигоряння; 3) професійно-емоційне вигоряння; 4) деперсоналізацію; 5) редукцію особистісних досягнень.

Професійно-когнітивне вигоряння науково-педагогічного працівника являє собою: у процесуальному плані - поступову втрату ним інтелектуальної активності, креативності та ефективності мислення; на результативному рівні інтелектуальну пасивність, ригідність і шаблонність мислення, відсутність новизни і творчості.

Професійно-вольове вигоряння науково-педагогічного працівника відображає: у процесуальному плані - поступову втрату волі до навчальної, наукової, методичної, виховної та організаційної діяльності, розв'язання різнобічних завдань освітнього процесу; в результативному аспекті - нездатність проявляти наполегливість, послідовність і твердість у реалізації завдань освітнього процесу. 
Професійно-емоційне вигоряння науково-педагогічного працівника полягає у поступовому зменшенні позитивних емоцій від професійної діяльності та її результатів аж до повного їх зникнення, а на результативному рівні - повну чи часткову відсутність позитивних емоцій, байдужість, емоційну холодність, емоційну відстороненість від професійної діяльності та її результатів.

Дослідниця Н. Чепелєва у своєму дисертаційному дослідженні емоційного вигоряння викладачів вищих навчальних закладів розглядає його «як варіант дезадаптації, при якому порушується контакт з реальністю; на безпосередньопсихологічному рівні емоційне вигоряння являється наслідком неадекватних дій, в основі яких лежить використання шаблонних і неадекватних ситуації засобів вирішення проблем, що неминуче виникають у професійній діяльності» [223, c. 65].

Деперсоналізація науково-педагогічного працівника - це відсутність у нього потреби в прояві своєї особистості, байдужість до оцінки іншими своїх особистісних, професійних i ділових якостей; деформація стосунків зі здобувачами вищої освіти й колегами по роботі тощо.

Редукція професійних досягнень науково-педагогічного працівника, яка виявляється як тенденція: 1) переоцінки ним своїх професійних досягнень та скептичного ставлення до них; 2) усвідомлення реальної чи уявної некомпетентності, неуспіху в професійній педагогічній діяльності, безперспективності.

Між психолого-педагогічною професійною надійністю науковопедагогічного працівника i його професійним вигорянням (психологопедагогічною професійною деформацією) наявна обернено пропорційна залежність (табл. 1). 
Обернено-пропорційна залежність між психолого-педагогічною професійною надійністю і професійним вигорянням науково-педагогічного працівника

\begin{tabular}{|l|l|}
\hline $\begin{array}{c}\text { Складники психолого- } \\
\text { педагогічної професійної надійності } \\
\text { НПП }\end{array}$ & \multicolumn{1}{c|}{$\begin{array}{c}\text { Складники психолого- } \\
\text { педагогічної професійної } \\
\text { деформації нпП }\end{array}$} \\
\hline Професійно-когнітивна надійність & Професійно-когнітивне вигоряння \\
\hline Професійно-вольова надійність & Професійно-вольове вигоряння \\
\hline Професійно-емоційна надійність & Професійно-емоційне вигоряння \\
\hline Персоналізація & Деперсоналізація \\
\hline Значущість особистісних досягнень & Редукція особистісних досягнень \\
\hline
\end{tabular}

Отже, психолого-педагогічна професійна надійність науковопедагогічного працівника утворює обернено пропорційну залежність 3 його психолого-педагогічною професійною деформацією, котра, своєю чергою, розвивається внаслідок професійного вигоряння, яке відображає професійнокогнітивне, професійно-вольове та професійно-емоційне вигоряння, деперсоналізацію і редукцію особистісних досягнень.

Тому професійно-конструктивний блок якості професійної діяльності науково-педагогічного працівника відображає наявність у нього таких складових як: 1) професійно-когнітивну надійність, що має обернено пропорційну залежність від професійно-когнітивного вигоряння; 2) професійно-вольову надійність, що має обернено пропорційну залежність від професійно-вольового вигоряння; 3) професійно-емоційну надійність, що має обернено пропорційну залежність від професійно-емоційного вигоряння; 4) персоналізацію, що має обернено пропорційну залежність від деперсоналізації; 5) значущість особистісних досягнень, що має обернено пропорційну залежність від редукції особистісних досягнень. 
Таким чином, доведено, що якість професійної діяльності науковопедагогічного працівника являє собою похідну від iï ефективності, котра $є$ доцільно спрямованою за змістом, освітніми функціями та завданнями його керованою, мотивованою, емоційно позитивною психолого-педагогічною взаємодією зі здобувачами вищої освіти, повною реалізацією ним власних знань, умінь, загальних і фахових компетентностей, здібностей, особистісних властивостей та якостей.

Нами розроблена та обгрунтована функціональна модель забезпечення якості професійної діяльності науково-педагогічного працівника, котра відтворює і процес забезпечення його ефективної професійної діяльності, і педагогічні умови, в яких досягається ефективність цього процесу, і можливість оцінювання результату іiі функціонування.

За структурно-функціональним характером модель забезпечення якості професійної діяльності науково-педагогічного працівника являє собою систему психолого-педагогічних елементів (блоків) зі заданими характеристиками i властивостями, певним чином узгоджених за змістом, часом i метою, функціонування яких відтворює процес спрямованої професійної активності науково-педагогічного працівника та його особистісної організації в ході взаємодії зі здобувачами вищої освіти з метою формування у них знань, навичок, вмінь, загальних і фахових компетентностей та особистісних якостей. Дана модель включає такі взаємопов'язані функціональні блоки: 1) знаннєвокомпетентнісно-особистісний, через котрий забезпечується підтримування необхідної сукупності знань, умінь, компетентностей, особистісних якостей і здібностей; 2) професійно-мотиваційний, через який забезпечується формування i підтримування в нього мотивації до досягнення успіху в професійній діяльності; 3) професійно-управлінський, котрий забезпечує ефективне управління ним освітнім процесом здобувачів вищої освіти; 4) професійноорієнтаційний, через який забезпечується його позитивна професійна спрямованість; 5) професійно-конструктивний, через який забезпечується його психолого-педагогічна професійна надійність, попередження розвитку 
професійної деформації. Кожний блок є відносно незалежною підсистемою в системі моделі, яка у функціональному плані розгортається як своєрідний процес, що перебігає за своїми закономірностями, але разом 3 іншими підсистемами, виходячи 3 їх синергійного характеру, в цілісному процесі функціонування моделі забезпечує певний рівень якості професійної діяльності науково-педагогічного працівника.

На основі функціонування знаннєво-компетентнісно-особистісного, професійно-мотиваційного, професійно-управлінського, професійноорієнтаційного та професійно-конструктивного блоків виявлено шістнадцять складових, які в сукупності забезпечують якість професійної діяльності науковопедагогічного працівника, а саме: 1) сукупність знань, умінь, компетентностей, необхідних якостей та їх ефективна реалізація в освітньому процесі; 2) комунікативні здібності; 3) організаційні здібності; 4) мотивація до успіху; 5) відсутність мотивації до уникнення невдачі, що має обернено пропорційну залежність від мотивації до уникнення невдач; 6) авторитарно-одноосібний стиль управління освітнім процесом здобувачів вищої освіти; 7) одноосібнодемократичний стиль управління освітнім процесом здобувачів вищої освіти; 8) відсутність пасивного стилю управління освітнім процесом здобувачів вищої освіти, що має обернено пропорційну залежність від пасивного стилю управління; 9) відсутність спрямованості на себе, що має обернено пропорційну залежність від спрямованості на себе; 10) відсутність спрямованості на взаємодію, що має обернено пропорційну залежність від спрямованості на взаємодію; 11) спрямованість на справу; 12) професійно-когнітивна надійність, що має обернено пропорційну залежність від професійно-когнітивного вигоряння; 13) професійно-вольова надійність, що має обернено пропорційну залежність від професійно-вольового вигоряння; 14) професійно-емоційна надійність, що має обернено пропорційну залежність від професійно-емоційного вигоряння; 15) персоналізація, що має обернено пропорційну залежність від деперсоналізації; 16) значущість особистісних досягнень, що має обернено пропорційну залежність від редукції особистісних досягнень. 